\title{
Mass Media and the Attribution of Blame for Globalization
}

\begin{abstract}
Much is known about the domestic politics of globalization but political scientists have largely ignored one critical link between the international economy and many individuals around the world: mass media. Considering the likely effects of mass media on public perceptions of responsibility, this article develops an argument about the effects of mass media on individuals' blame attributions for the adjustment costs of economic globalization. The theory is tested on survey data from France in 1992-1993. The evidence suggests that mass media may shift the public's blame attributions away from the government and toward external, international forces.
\end{abstract}

Keywords: media, globalization, blame, public opinion

Although the relationship between economic globalization and the modern welfare state has been one of the most studied issues in political economy over the past three decades (e.g., Gourevitch 1978; Garrett 1995; Rodrik 1998; Adserà and Boix 2002; Oatley 2011, 316), recent research on public opinion and political behavior in open economies raises questions about the assumptions of this tradition (Hellwig 2007, 155). A fundamental assumption in globalization-welfare research, which dates back to Karl Polanyi's The Great Transformation, is that policymakers who wish to liberalize economic markets are held accountable by those groups who would suffer the adjustment costs (Polanyi [1944] 2001, 79, 385). Scholars have shown that to sustain political coalitions in favor of opening national economies, national policymakers have to compensate protectionist domestic groups with side payments in the form of social welfare programs (Katzenstein 1985; Rodrik 1998; Adserà and Boix 2002, 1028-29).

However, research in comparative political behavior shows that as domestic economies become increasingly integrated, citizens perceive that governments have less "room to maneuver" and accordingly shift their blame away from domestic policymakers to the unaccountable pressures of the global economy (Alcañiz and Hellwig 2010; Hellwig 2014). 
Citizens in countries highly exposed to the global economy are less likely to punish incumbents for a poorly performing economy (Hellwig and Samuels 2007) and more likely to base their vote on non-economic issues (Hellwig 2008). If domestic groups do not punish politicians for economic losses made possible by the political decisions to maintain open national economies, then an essential causal link in current accounts of the globalization-welfare nexus may not hold under certain conditions. Furthermore, this current of research has yet to take seriously that economic globalization does not inherently constrain policymakers' "room to maneuver" but rather has been socially constructed as such by elites and typically through the mass media (Hay and Rosamond 2002; Hay and Smith 2005; Hay 2002).

At the same time, previous research has shown that mass media have direct effects on perceptions relevant to how citizens are likely to understand the politics of globalization. Specifically, mass media are believed to have direct effects on perceptions of responsibility (Iyengar 1987; Iyengar 1991), the politicization of economic hardship (Mutz 1992; Mutz 1994), and civic engagement more broadly (Putnam 1995; Norris 2000). I argue that by amplifying the dominant construction of globalization as an external imperative constraining policymakers, mass media exposure should shift citizen blame attributions away from governments and toward international forces.

These expectations are tested with data from France between 1992 and 1993, measuring perceptions of national problems, responsibility attributions, and media exposure. The data provide a unique opportunity to test the argument that mass media has independent effects on individuals' perceptions and blame attributions around issues of economic openness. I will argue that France in the early 1990s represents a least-likely case for observing the hypothesized media effects because economic globalization was highly politicized and widely seen as a policy 
question. A battery of statistical analyses show that mass media exposure is positively associated with individuals' perceptions of economic openness as a problem and then, controlling for whether economic openness is perceived as a problem, the attribution of blame to international forces. In turn, blame attributions predictably shape evaluations of the incumbent government, as individuals more likely to blame international forces are more favorable toward the incumbent government.

The findings challenge prevailing wisdom in at least two ways. First, the article contributes to research on individual-level determinants of public opinion in the context of globalization. The findings provide additional evidence for the literature that suggests economic openness makes citizens less likely to blame, and less likely to punish, incumbent governments for poor economic performance, but they also provide novel evidence that mass media exposure may be an independent and additional causal path to the same effect, controlling for perceptions of economic openness. The findings therefore have implications for research in comparative politics as they contribute to the call for a more political accounting of the domestic effects of globalization (Kayser 2007, 341) and for a more rigorous examination of the micro-foundations of work in this area (Hays, Ehrlich, and Peinhardt 2005; Walter 2010).

The article proceeds as follows. In the first section, previous literature is reviewed to reveal a gap between comparative and international political economists on the one hand and scholars of public opinion and political behavior on the other. Mass media research is situated within this gap, and research on the French context is discussed. A second section develops specific hypotheses regarding how mass media is likely to affect individual perceptions, blame attributions, and evaluations of government. A third section discusses the data and modeling strategy, the penultimate section discusses the core findings, and a final section concludes. 


\section{Mass Media Between Globalization and Domestic Politics}

Previous research has questioned the degree to which economic liberalization enters into voters' perceptions, or whether institutions moderate public perceptions and the electoral consequences of liberalization. For instance, Guisinger (2009) finds that trade policy may not be sufficiently salient, even to the most affected groups, to justify voter-driven models of trade policy. Baker $(2003 ; 2005 ; 2009)$ argues that, especially in the developing world, public support for trade openness remains high because it is associated with relatively high-quality goods at relatively low prices, despite sometimes dramatic negative macro-economic consequences. Such findings highlight pathways through which certain negative effects of trade liberalization can have different effects on individuals, depending on how they are perceived. Baker's finding of high support for free trade even in national contexts of dramatic negative macro-economic consequences, only adds scholarly interest to the puzzle of precisely how and why individuals come to find consumption effects more salient than other effects of trade liberalization.

Other research also suggests causal pathways through which citizens harmed by the adjustment costs of liberalization would not hold policymakers accountable for the political decision of liberalization. First, research mostly from advanced democratic countries finds that as the sources of economic growth shift, citizens accordingly adjust their expectations of government policymaking and their attributions of blame for national problems. Using time-series data from France between 1985 and 2002, Hellwig (2007) shows that as exposure to trade and capital flows increase, citizens becomes less confident in the ability of national policymakers to solve national problems and the public demand for economic policy solutions decreases. Voters also adjust their judgment of governments in predictable ways as other 
components of the institutional context change. For instance, when the Bank of England gained political independence, British voters were less likely to base their evaluation of the government on monetary policy and more likely to base it on fiscal policy (Sattler, Brandt, and Freeman 2010).

Secondly, perceptions and blame attributions affect political outcomes by altering that for which policymakers can be held accountable. Analyzing all 560 democratic elections between 1975 and 2002, Hellwig and Samuels (2007) show that as trade and capital flows increase as a share of gross domestic product, domestic economic growth rates have a smaller effect on incumbent vote share. Cross-sectional analyses of French and British survey data from 1997 and 2001, respectively, show similar effects of globalization on the determinants of vote choice, decreasing the effect of voter's economic performance evaluations and party positions on economic issues (Hellwig 2008). Perceptual shifts in the ability of governments to affect economic policy also affect voter turnout. Analysis from the United States has found that individuals who suffer economic adversity but do not blame the government are less likely to vote than comparable individuals who do blame the government (Arceneaux 2003). In terms of policymaking, elite messaging in the mass media (Hellwig and Coffey 2011) and interviews with party elites in Europe (Hellwig 2014, 38, 137) confirm that politicians consciously stress globalization constraints on their own behavior.

Finally, changes in the institutional setting are found to have predictable moderating effects on the responsiveness of policy to public opinion. For instance, Sattler, Brandt, and Freeman (2010) show that before central bank independence, British fiscal and monetary policies were responsive to aggregate voting intentions and government approval ratings but, after central bank independence, monetary policy was no longer responsive. Interestingly, however, Sattler, 
Freeman, and Brandt (2008) find mutual responsiveness between public opinion and policy outputs, despite a lack of responsiveness in policy outcomes such as inflation and economic growth. That this responsiveness is observed outside real economic outcomes is accredited to the difficulty of identifying the effects of policies in open economies.

Given that public perceptions of the institutional context have been shown to affect political consequences of the economy, it is puzzling that scholarship on the domestic politics of economic globalization has largely neglected a serious inquiry into political communication and the mass media in particular. Scholars of American politics have shown that national policymakers actively engage in strategies of "blame avoidance" through the mass media (Weaver 1986; Jacobson and Kernell 1983), diffusing blame horizontally toward other equals or vertically upward in the chain of authority (McGraw 1990, 1991). Variation in blame attributions, in turn, has predictable effects on how individuals judge both policies and policymakers (McGraw, Best, and Timpone 1995). Other work has shown that under certain conditions mass media can diffuse blame through issue framing (Iyengar 1987; Iyengar 1991), depoliticize personal experience in favor of sociotropic perceptions (Mutz 1992), and exacerbate inequalities in political participation (Norris 2000). Hood $(2002,20)$ suggests that by lowering the potential costs of communicating malign policy effects to harmed groups, mass media may increase the incentives for politicians to avoid blame.

In light of these currents of research, it is a surprising omission in previous research on the domestic politics of globalization that testimony by party elites in research interviews (Hellwig 2014, 38, 137) and via the mass media (Hellwig and Coffey 2011, 420-21) is more often cited as evidence of room-to-maneuver constraints than questioned as possible strategic communication or media bias. Especially because evidence for opinion-policy responsiveness in 
open economies can be observed apart from and despite the objective economic effects of policy (Sattler, Freeman, and Brandt 2008), a necessary next step in studying the domestic politics of globalization is to theorize more specifically how political communication - in particular, the mass media - may directly and indirectly affect the relationship between objective patterns of economic openness and domestic political outcomes.

In some countries, such as France, economic globalization was a highly politicized and contested phenomenon during the 1990s (Desbos and Royall 2011). Public debate over the 1992 referendum on the Maastricht Treaty was one of the first major events to spark a public debate about globalization in France (Ancelovici 2002, 431). As Ancelovici shows, the 1990s were characterized by a public debate framed as "Politics against Global Markets," in which the economic effects of globalization were routinely denounced in favor of national and local government action to mitigate its effects. In her review of research on the politics of globalization, Suzanne Berger (2000) points out that in France, criticism of globalization often suggested that "the problems appear to have political origins, they appear reversible by government action." French media also tends to provide a wider range of perspectives than many other countries. Benson (2009) finds that French national newspapers are characterized by greater ideological pluralism than U.S newspapers because of less funding for advertising, audiences with higher cultural capital, and the French "debate ensemble" method of mixing news, editorials, and context. Benson and Hallin (2007) find in their study of both Le Monde and Le Figaro that the French press, compared to the US press, offers more critical coverage reporting more thoroughly on the various ideological and strategic interests of actors.

Therefore a country such as France, during a period such as the early 1990s, represents a relatively high baseline for the tendency of the public to see globalization as a debatable policy 
issue, the responsibility for which would most naturally be assigned to government. As I discuss further in the section on Data and Method, this will be an ideal testing ground for the theory presented here.

\section{Theory and Hypotheses}

Previous research has shown that economic liberalization or openness usually is socially constructed by elite opinion-leaders as an external and objective process that constrains policymakers' room-to-maneuver (Hay 2002; Hay and Smith 2005; Hay and Rosamond 2002). The central, novel theoretical claim of this article is that the mass media diffuse responsibility for policies of economic liberalization over and above whatever diffusion of responsibility is created by the objective realities of economic openness. The warrant for this claim is straightforward: mass media amplify and extend the reach of elite-sponsored social constructions beyond the reach they would have in the absence of mass media. This section develops the reasoning behind this central claim and then deduces a series of hypotheses regarding how mass media should be expected to affect individuals' perceptions of economic openness and blame attributions for national problems.

Previous research already reviewed demonstrates that the dominant social construction of economic globalization - the one consistently endorsed in interviews with elites and in mass media messaging (Hellwig 2014, 38, 137; Hellwig and Coffey 2011, 420-421) - is that of an external, objective pressure on policymaking (Hay 2002; Hay and Smith 2005; Hay and Rosamond 2002). Given this general elite consensus, standard theories of media coverage lead to the expectation that the media will tend to amplify this particular social construction. The "indexing" theory of news coverage suggests that the distribution of news coverage on a 
particular political issue will tend to follow the distribution of elite opinion on that issue (Bennett 1990; Zaller and Chiu 1996; Bennett, Lawrence, and Livingston 2006). The indexing theory of news coverage would suggest that mass media is more likely to represent economic globalization as an external constraint on policymaker autonomy rather than alternative critical narratives attributing responsibility to governments for negative consequences of globalization. Adding to the indexing theory the general responsibility-diffusing tendencies inherent to mass media discussed above, such as its episodic nature and the prevalence of elite blame avoidance, the overall expectation is that mass media should amplify the dominant construction of economic globalization as an external pressure which imposes itself on domestic policymakers, rather than an outcome of policymaking for which policymakers might be held responsible.

To be clear, my argument is not that there exists one single editorial line about globalization across diverse media outlets. Rather, I have argued that the diversity of opinions one finds across mass media revolve around a dominant social construction of globalization that is implicitly blame-diffusing (the notion that it is an "external constraint"). In addition, because of the indexing phenomenon, practices of elite blame avoidance, and episodic coverage effects, my argument is that despite editorial diversity we should expect mass media in general to exert blame-diffusing effects on perceptions of economic globalization.

The theory leads to two different versions of a first hypothesis, one implying an indirect effect and the other implying a direct effect. Mass media may have an indirect effect on how individuals attribute blame for national problems, by informing individuals of objective problems pertaining to economic openness (merely transmitting information about objectively constraining realities pertaining to economic openness). The stronger version of this argument is that mass media may have a direct effect on how individuals attribute blame for national problems, 
uniquely diffusing responsibility in their perception of national problems above and beyond its effect of making individuals more aware of the problems of economic openness. This effect is expected directly (by diffusing political responsibility in general, controlling for perceptions of openness as a problem) and indirectly (by increasing awareness of openness as politically problematic).

Hypothesis 1: Individuals more exposed to mass media are more likely to blame international forces for national problems than individuals less exposed to mass media.

A second hypothesis captures implications of previous research suggesting that perceptions of a policymaker's "room to maneuver" affect how individuals evaluate government performance. If the effect of economic perceptions on vote choice weakens because increasing economic openness shifts blame attributions toward the global economy and away from governments, then blame attributions should be associated with evaluations of government economic performance. Thus, I hypothesize that individuals who blame international forces for national economic problems should be more favorable toward incumbent governments than those who blame the government.

Hypothesis 2: Individuals who blame international forces for national problems evaluate incumbent governments more favorably than individuals who blame the government for national problems.

It stands to reason that various individual-level factors might condition this general expectation. Political partisanship, political interest and/or knowledge, economic anxiety, and various other factors might deserve to be included not only as control variables (as they are here, data permitting) but as interaction terms capturing the heterogeneity of effects. While a great 
number of additional complicating factors are plausible, in this first study of media as a moderator of the globalization-welfare nexus, I restrict attention to testing this one set of general causal links. Future research may then investigate various plausible forms of causal complexity within the general arguments and evidence presented here.

[Figure 1 about here]

Figure 1 summarizes the causal model linking perceptions to blame attributions, and blame attributions to evaluations of incumbent governments. The top half of the figure illustrates the expected causal flow we would expect to find in an idealized, non-globalized and non-massmediated context: to the degree voters perceive the national economy as the problem, they will blame the government, and express correspondingly negative evaluations of the government (a necessary condition for holding them accountable). The bottom half of the figure illustrates the expected causal flow in a globalized, mass-mediated context: to the degree voters perceive the policy-constraining implications of economic globalization as the problem, they will blame international forces rather than the government (thus breaking a necessary condition for electoral accountability around international economic policymaking). Crucially, the bottom half of the figure also illustrates the two possible effects of mass media in this process: exposure to mass media is expected to indirectly shift blame attributions toward international forces by increasing awareness of the policy-constraining implications of globalization, and/or directly by increasing international blame attributions beyond that which is due to receiving information about the policy-constraining implications of globalization. 


\section{Data and Method}

To test the theory, I use unique individual-level data from a Legidoscope survey of public opinion in France between 1992 and 1993 (Chrique 1997). The survey asks respondents several questions tapping blame attribution, media exposure, and evaluations of the government. ${ }^{1}$ Respondents are asked to identify their main source of information from among the following: friends, family, opinion leaders, and mass media. Respondents are also asked to identify the top two problems facing France, and whether individuals, social institutions, the government, or international forces beyond government control are to blame for the problem. ${ }^{2}$ Finally, respondents are asked about their satisfaction with President Mitterrand, how well they think the government is handling the problem identified by the respondent as a top problem, and their intention to turnout for the March 1993 elections. Before analysis, all numerical independent variables were de-meaned and divided by two standard deviations so that coefficients reflect the expected effect of a two standard deviation increase in the variable and are therefore roughly comparable to the coefficients for any categorical independent variables.

These data from France in the early 1990s provide a uniquely useful opportunity for testing hypotheses about the role of media in generating perceptions of room-to-maneuver constraints. First, while other surveys gauge perceptions of responsibility on many issues, and many other surveys gauge media exposure, this is the only survey known to the author that effectively gauges both perceptions of responsibility for issues of economic openness and media

\footnotetext{
${ }^{1}$ See Supplementary Information for the text of the survey questions and summary statistics.

${ }^{2}$ Respondents were asked to identify national problems in an open-ended fashion; their answers were then coded by the interviewer and into the general problem types listed here. To create the binary variable which measures whether the respondent sees some aspect of international economic openness as a top problem, I coded respondents as 1 if they identified one of the following issues as one of the "second most important problems": "Intl economic competition," "EC-92, economic integration," "Foreign trade," "Ratification of Maastricht," and "Maastricht Treaty." All other respondents were coded as 0 for the variable OpennessProblem.
} 
exposure. Second, France in this time period is a hard or least-likely case for testing the hypotheses, so evidence for the hypotheses would suggest such a process is likely to occur in other countries as well.

As discussed in the literature review, France in the 1990s was a political context in which the debate about globalization was an atypically open, multi-perspectival debate casting globalization as a policy rather than an inexorable global force. The Maastricht Treaty was highly salient in France at this time and the causes of economic openness were clearly linked to high-visibility policy decisions. Not long after the survey was conducted, the Parti Socialiste would be defeated in the polls in 1993 and a social movement would emerge in 1995 in response to issues of globalization and the neoliberal reforms of Alain Juppé. Union strikes commanding broad public support brought much of the country to a halt in 1995, and reflected substantial public discontent regarding the effects of Europeanization and globalization on the French welfare state (Schmidt 2007, 1001). If, in such a context, media were found to be an independent cause of voters' perceptions of globalization as an external constraint, we could be confident the same would hold true in more common contexts where the policy-caused aspects of economic liberalization are less salient. Additionally, relative to many countries France has high rates of political engagement, and a statist, egalitarian political culture in which elite opinion claims more control over globalization than in countries such as Italy or the United Kingdom (Hay and Rosamond 2002, 159). Evidence that media shifts blame attributions from government to international forces, observed in France in the early 1990s, should generalize to many other national situations in which baseline perceptions of government control over globalization would be lower.

To test the direct and indirect effects of mass media on blame (Hypothesis 1), I estimate 
two logistic regression models. The first estimates the probability a respondent will blame international forces as a function of mass media exposure and a vector of control variables including controls for the nature of the problem. The equation (1) is:

$$
\text { Blame }_{i}=\alpha+\beta 1 \text { ProblemArea }_{i}+\beta 2 \text { OpennessProblem }_{i}+\beta 3 \text { Media }_{i}+\beta 4 \text { Controls }_{i}+e_{i}
$$

Blame is a binary variable taking a value of 1 for respondents who blame international forces and 0 for respondents who blame the government for whichever national problem they have identified. ${ }^{3}$ ProblemArea is a categorical variable with four levels indicating whether the problem deals with social, economic, political, or foreign issues. ${ }^{4}$ OpennessProblem is a binary variable I constructed to take a value of 1 for respondents who identified a problem specifically related to economic openness and 0 otherwise. If the mass media have an independent effect on diffusing blame away from government policymakers and toward international forces, then we would expect $\beta 3$ to be positive and significant.

Then, to assess the indirect effect of mass media on blame as its channeled through perceptions of economic openness, I estimate a logistic regression modeling the probability of

\footnotetext{
${ }^{3}$ Because of space constraints and for ease of interpretation in light of the hypotheses under consideration, I consider here only the difference between blaming the government and blaming international forces, omitting respondents who placed the blame on "society" or "people like you and me." However, the results obtained here are robust to alternative specifications in which the dependent variable takes a value of 1 for respondents who blame international forces and 0 for respondents who select any of the other possible targets of blame. See Supplementary Information for results from alternative specifications.

${ }^{4}$ In the first wave of the survey, so many respondents identified unemployment as the top problem facing France that a question was added to measure what respondents identified as the "second most important problem facing France today." All the analyses here, including the variables measuring blame attributions and evaluations of government handling, refer to this second most important problem.
} 
perceiving openness as a top problem as a function of mass media exposure and a vector of control variables:

$$
\text { OpennessProblem }_{i}=\alpha+\beta 1 \text { ProblemArea }_{i}+\beta 2 \text { Media }_{i}+\beta 3 \text { Controls }_{i}+e_{i}
$$

Here the main variables of interest are the same as in Equation 1 except that the dependent variable is the binary variable capturing whether openness is perceived as a top problem. If mass media affect blame attributions indirectly by making individuals more likely to perceive economic openness as a problem, then $\beta 2$ should be positive and significant.

To test Hypothesis 2 regarding the effect of blame attributions on evaluations of the government, I estimate a linear regression modeling how individuals evaluate the government's handling of the problem they identified as one of the most important facing the country. I model evaluations of government handling as a function of respondents' blame attributions and a vector of control variables. The equation is:

GovHandling $_{i}=\alpha+\beta 1$ ProblemArea $_{i}+\beta 2$ OpennessProblem ${ }_{i}+\beta 3$ Blame $_{i}+\beta 4$ Controls $_{i}+e_{i}$ (3)

GovHandling measures, on a scale from 1 to 4 , how a respondent evaluates the government's handling of whichever top problem the respondent identified. The theory predicts that for a particular problem such as the domestic costs of economic openness, blaming international forces rather than the government will make individuals less likely to critically update their evaluations of the government (negatively). If this is the case, then individuals who think a problem is caused by forces outside of the government's purview should be less critical 
of the government's handling of that problem. In this case, then, the theoretical expectation is that $\beta 3$ will be positive and significant, reflecting that blaming international forces for a problem leads individuals to view the government's handling of that problem more favorably than if they blamed the government for the problem.

\section{Findings and Discussion}

The coefficient plots in Figures 2 and 3 reveal statistical results broadly consistent with Hypothesis 1 regarding the expectation that mass media diffuse blame for national problems away from governments and toward international forces. ${ }^{5}$ Reliance on media is independently correlated with blaming international forces (consistent with a direct effect of media) and weakly correlated with perceptions of openness as a problem (consistent with an indirect effect of media). Respondents who rely on the mass media as their most important source of information are significantly more likely to blame international forces for what they identify as one of the nation's top problems (a logit estimate of .35 and standard error of .12), even controlling for perceptions of economic openness as a problem and the more general issue area in which a respondent locates that problem. To get a better sense of the effect size, consider probabilities. Based on 1000 simulations, the probability of blaming international forces for a typical individual who does not rely primarily on the mass media for information is $.33 .{ }^{6}$ Relying primarily on mass media increases this probability to .41 (a mean change of .08 with a standard deviation of .03). Also, as we would expect from previous research on public opinion and voting

\footnotetext{
${ }^{5}$ Numerical model results are included in Supplementary Information. All models were estimated with the Zelig package in R (Imai, King, and Lau 2009).

6 "Typical" refers to mean values on the numerical independent variables and the reference levels for categorical variables, i.e., in this case, a non-urban, non-university-educated, non-whitecollar, non-left-party male at the mean age and with mean levels of political interest, who identifies the second top problem as "Economic" and not related to economic openness.
} 
in open economies, the perception of economic openness as a problem also increases the probability a respondent will blame international forces for that problem. ${ }^{7}$ Indeed, of all the variables considered here, the perception of economic openness as one of the nation's top problems is the strongest determinant of whether a respondent will blame international forces for that problem (a logit estimate of 1.1 and standard error of .14). In this case, for a typical individual who identifies a top problem other than one of openness, the probability of blaming international forces is .41 but for the same individual who identifies a top problem related to openness, that probability increases to .68 (a mean increase of .26 and standard deviation .03). I also estimated additional models where the binary dependent variable opposes each of these targets of blame to anyone who blames any other target. The results are consistent with those presented here. ${ }^{8}$

[Figure 2 about here]

[Figure 3 about here]

Model 2 considers the indirect effect of mass media on blame attributions through their effect on perceptions of openness as a problem. Reliance on mass media has a positive marginal effect on the perception of openness as a problem (a logit estimate of .33 and standard error of

\footnotetext{
${ }^{7}$ It could be the case that individuals with cosmopolitan outlooks are more interested in mass media because of their greater interest in global issues, in which case mass media exposure could be endogenous to knowledge of issues surrounding economic globalization. Although the survey data used in this paper provide no measure of overall interest in international affairs, the analyses below control for the best predictors of cosmopolitanism: education, class, and general interest in politics. Because these are the best predictors of cosmopolitanism, it seems unlikely that observing an independent effect of mass media exposure would be spurious due to this particular risk of endogeneity.

${ }^{8}$ See Supplementary Information.
} 
$.17 ; \mathrm{p}=.06$ ). For a typical individual who does not rely primarily on mass media, the probability of perceiving an issue of openness to be a top problem is .08; relying on mass media increases this probability by a mean of .03 (standard deviation $=.01$ ) to .11 . Thus, the indirect effect of mass media on blaming international forces, through its slight marginal effect on the perception of openness as a problem, is only .01 (.26*.03). In short, the results provide some evidence that mass media may affect blame attributions through the pathway of increasing perceptions of openness as a top problem, but it is relatively weak evidence of only a small effect.

[Figure 4 about here]

The coefficient plot for Model 3, testing Hypothesis 2, reveals statistical evidence for the expectation that blaming international forces, in turn, has a positive effect on evaluations of the government $($ logit estimate $=.38$, standard error $=.03)$. Simulating quantities of interest suggests that blaming international forces for a top problem increases a typical individual's evaluation of government handling by .38 (standard deviation $=.03$ ), from 1.6 to 2.0 on the four-point scale of the dependent variable. These results also hold when the dependent variable refers to satisfaction with the President rather than government handling of a top problem, and to an expanded operationalization of the blame variable considering the government, international forces, and other possible targets. ${ }^{9}$

Thus the results provide evidence consistent with each essential step of the causal chain, though the estimated indirect effect of mass media on diffusing blame (through increasing perceptions of openness as a problem) is weak. Nonetheless, the evidence suggests that mass media directly diffuse blame away from governments toward international forces (increasing the ${ }^{9}$ See Supplementary Information. 
probability of blaming international forces by about $8 \%$ ) even controlling for the general issue area in which the respondent locates a top problem and whether it is related to openness.

There is reason to suppose that blame attributions could be endogenous to evaluations of how the government is handling a problem, in the sense that perceptions of poor or satisfactory government handling could increase or decrease the government's perceived culpability. First, however, it should be recalled that the survey question used to measure blame attributions refers specifically to the cause of the problem. Thus, strictly speaking, evaluations of how the government handles the problem should not affect who or what individuals identify as the cause or source of the problem. Second, it is much harder to believe that evaluations of government handling could drive individuals' blame of international forces or blame of the two alternative targets from which respondents were able to choose (individuals "like you and I" or social institutions) simply because it is hard to imagine how government handling of the problem could make any of these other targets more or less culpable. Thus, I estimate an additional model that has separate binary independent variables for blaming government, international forces, or "other" as the baseline (see Supplementary Information). The coefficient for blaming government is larger than that for blaming international forces but both remain signed as expected and significant. This alternative specification mitigates the possibility that blaming international forces merely reflects respondents who are less likely to blame the government.

\section{Conclusion}

This study has presented evidence that mass media conditions a key link in the causal chain linking economic globalization to domestic politics. Survey evidence from France shows that individuals most reliant on mass media are less likely to blame top national problems on 
incumbent governments, and more likely to blame international forces. Mass media indirectly deflects (weakly) blame away from incumbent governments and toward international forces by making individuals more aware of economic openness as a political issue, but it also directly decreases individuals' propensities to blame incumbents relative to international forces (controlling for the awareness effect), most likely due to the responsibility-diffusing framing effects previously found in mass media studies. In turn, I find that individuals who blame international forces rather than the government evaluate the government more favorably. The key implication is that mass media may weaken one basis of electoral accountability for international economic policymaking. Mass media may diffuse the domestic political pressure against liberalization that has historically elicited welfare-state compensation for aggrieved domestic groups.

I have argued that France in the early 1990s is an attractive testing ground for the theory that media diffuses blame attributions because it provides least-likely conditions for finding evidence of the theory: insofar as France in the 1990s represented an atypically high baseline for the public tendency to see globalization as a policy decision and therefore attributable to government, evidence that media dampens government blame attributions in such a context suggests such a tendency will also be observed in more typical contexts where the theory appears even more likely to hold. Nonetheless, given the national and historical context of the sample used in this study, there are still important limitations to the conclusions that can be drawn. The first and most obvious issue is that many national media environments are dramatically different today than they were in the early 1990s. Has the rise of the world-wide web and now social media affected the blame-diffusing effect of mass media reported here? Qualitative and quantitative aspects of international economic integration have also changed much since the 
early 1990s. Does the current rise of populist, right-wing economic nationalism reflect a fundamentally different relationship between globalization, media, and public opinion? Clearly these are important questions this study cannot answer. More research using more contemporary data, ideally across multiple countries, will be necessary to make headway on these more general questions.

Other limitations of this study also point to other avenues for future research. While I considered many dominant rival hypotheses through the use of statistical control variables, this article could not engage with all possible factors that may plausibly condition the relationships posited by the hypotheses presented. For instance, it seems likely that political partisanship may condition the relationship between media exposure and blame attributions, and/or the relationship between blame attributions and evaluations of government. Thus, rather than simply controlling for partisanship as above, future research might investigate whether these relationships are dampened or amplified under different conditions of citizen and government partisanship.

Finally, the findings have other implications for the study of international and comparative politics. This article contributes to current research agendas seeking more finelytuned political accounts of the domestic effects of globalization (Kayser 2007, 341) and a better understanding of public opinion and voting behavior in the context of economic openness (Hellwig 2008). The findings should also be of particular interest to scholars seeking more rigorous micro-foundations for the relationship between economic openness and welfare states (Hays, Ehrlich, and Peinhardt 2005; Walter 2010). The unique national and historical context of the dataset constrains our capacity to generalize, but the results of this study nonetheless suggest that from the standpoint of democratic values, mass media potentially could have subtle but 
perverse effects on the distributive politics of open economies, if the blame-diffusing effects on public opinion discourage domestic groups from holding national policymakers accountable for the unevenly distributed costs of globalization.

(7,390 words including notes and references, excluding abstract and 4 figures) 


\section{References}

Adserà, Alícia, and Carles Boix. 2002. "Trade, Democracy, Public Sector: The Political Underpinnings of Openness.” International Organization 56(2): 229-262.

Alcañiz, Isabella, and Timothy Hellwig. 2010. "Who's to Blame? The Distribution of Responsibility in Developing Democracies." British Journal of Political Science 41(2): 389-411.

Ancelovici, Marcos. 2002. "Organizing against Globalization: The Case of ATTAC in France." Politics \& Society 30(3): 427-63.

Arceneaux, Kevin. 2003. "The Conditional Impact of Blame Attribution on the Relationship Between Economic Adversity and Turnout." Political Research Quarterly 56(1): 67-75.

Baker, Andy. 2003. "Why Is Trade Reform So Popular in Latin America?: A ConsumptionBased Theory of Trade Policy Preferences." World Politics 55(3): 423-55.

Baker, Andy. 2005. "Who Wants to Globalize? Consumer Tastes and Labor Markets in a Theory of Trade Policy Beliefs.” American Journal of Political Science 49(4): 924-938.

Baker, Andy. 2009. The Market and the Masses in Latin America: Policy Reform and Consumption in Liberalizing Economies. Cambridge: Cambridge University Press.

Bennett, W Lance. 1990. "Toward a Theory of Press-State Relations in the United States." International Studies Quarterly 40(2): 103-127.

Bennett, W Lance, Regina G Lawrence, and Steven Livingston. 2006. "None Dare Call It Torture: Indexing and the Limits of Press Independence in the Abu Ghraib Scandal." International Studies Quarterly 56(3): 467-485.

Benson, Rodney. 2009. "What Makes News More Multiperspectival? A Field Analysis.” Poetics 37(5-6): 402-18.

Benson, Rodney, and Daniel C. Hallin. 2007. "How States, Markets and Globalization Shape the News." European Journal of Communication 22(1): 27-48.

Benson, Rodney et al. 2012. "Media Systems Online and Off: Comparing the Form of News in the United States, Denmark, and France.” Journal of Communication 62(1): 21-38.

Berger, Suzanne. 2000. "Globalization and Politics," Annual Review of Political Science 3: 44. 
Chrique, Philippe. 1997. Legidoscope: Trend Surveys of French Public Opinion and Media Usage, September 1992-May 1993. Inter-university Consortium for Political and Social Research (ICPSR) [distributor]. http://doi.org/10.3886/ICPSR06826.v1.

Desbos, Clément, and Frédéric Royall. 2011. "Globalization and Political Posturing on the Left in France in the 1990s." French Politics 9(2): 139-57.

Garrett, Geoffrey. 1995. "Capital Mobility, Trade, and the Domestic Politics of Economic Policy." International Organization 49(4): 657-87.

Gourevitch, Peter. 1978. "The Second Image Reversed: The International Sources of Domestic Politics.” International Organization 32(4): 881-912.

Guisinger, Alexandra. 2009. "Determining Trade Policy: Do Voters Hold Politicians Accountable?" International Organization 63(3): 533-57.

Hay, Colin. 2002. "Globalisation as a Problem of Political Analysis: Restoring Agents to a 'Process without a Subject' and Politics to a Logic of Economic Compulsion*." Cambridge Review of International Affairs 15(3): 379-92.

Hay, Colin, and Ben Rosamond. 2002. "Globalization, European Integration and the Discursive Construction of Economic Imperatives." Journal of European Public Policy 9(2): 14767.

Hay, Colin, and Nicola Smith. 2005. "Horses for Courses? The Political Discourse of Globalisation and European Integration in the UK and Ireland." West European Politics 28(1): $124-58$.

Hays, Jude C., Sean D. Ehrlich, and Clint Peinhardt. 2005. "Government Spending and Public Support for Trade in the OECD: An Empirical Test of the Embedded Liberalism Thesis." International Organization 59(2): 473-94.

Hellwig, T, and D Samuels. 2007. "Voting in Open Economies: The Electoral Consequences of Globalization." Comparative Political Studies 40(3): 283-306.

Hellwig, Timothy. 2007. "Globalization and Perceptions of Policy Maker Competence: Evidence from France." Political Research Quarterly 60(1): 146-158.

Hellwig, Timothy. 2008. "Globalization, Policy Constraints, and Vote Choice." The Journal of Politics 70(4): 1128.

Hellwig, Timothy. 2014. Globalization and Mass Politics: Retaining the Room to Maneuver. Cambridge: Cambridge University Press.

Hellwig, Timothy, and Eva Coffey. 2011. "Public Opinion, Party Messages, and Responsibility for the Financial Crisis in Britain." Electoral Studies 30(3): 417-426. 
Hood, Christopher. 2002. "The Risk Game and the Blame Game." Government and Opposition 37(1): 15-37.

Imai, Kosuke, Gary King, and Olivia Lau. 2009. Zelig: Everyone’s Statistical Software. http://gking.harvard.edu/zelig.

Iyengar, Shanto. 1987. “Television News and Citizens' Explanations of National Affairs.” The American Political Science Review 81(3): 815-31.

Iyengar, Shanto. 1991. Is Anyone Responsible? How Television Frames Political Issues. Chicago: University of Chicago Press.

Jacobson, Gary C, and Samuel Kernell. 1983. Strategy and Choice in Congressional Elections. 2nd ed. New Haven: Yale University Press.

Katzenstein, Peter J. 1985. Small States in World Markets: Industrial Policy in Europe. Ithaca, NY: Cornell University Press.

Kayser, Mark Andreas. 2007. "How Domestic Is Domestic Politics? Globalization and Elections." Annual Review of Political Science 10(1): 341-362.

McGraw, Kathleen M. 1990. “Avoiding Blame: An Experimental Investigation of Political Excuses and Justifications.” British Journal of Political Science 20(1): 119.

McGraw, Kathleen M. 1991. "Managing Blame: An Experimental Test of the Effects of Political Accounts." American Political Science Review 85(4): 1133-1157.

McGraw, Kathleen M, Samuel Best, and Richard Timpone. 1995. "What They Say or What They Do?' The Impact of Elite Explanation and Policy Outcomes on Public Opinion." American Journal of Political Science 39(1).

Mutz, Diana C. 1992. "Mass Media and the Depoliticization of Personal Experience." American Journal of Political Science 36(2): 483-508.

Mutz, Diana C. 1994. "Contextualizing Personal Experience: The Role of Mass Media." The Journal of Politics 56(3): 689.

Norris, Pippa. 2000. Virtuous Circle. Political Communications in Postindustrial Societies. Cambridge: Cambridge University Press.

Oatley, Thomas. 2011. "The Reductionist Gamble: Open Economy Politics in the Global Economy." International Organization 65(2): 311-341.

Polanyi, Karl. 1944. The Great Transformation: The Political and Economic Origins of Our Time. 2nd ed. Boston: Beacon Press. 
Putnam, Robert D. 1995. "Tuning In, Tuning out: The Strange Disappearance of Social Capital in America." PS: Political Science \& Politics 28(4): 664-683.

Rodrik, Dani. 1998. “Why Do More Open Economies Have Bigger Governments?” Journal of Political Economy 106(5): 997-1032.

Ruggie, John Gerard. 1982. "International Regimes, Transactions, and Change: Embedded Liberalism in the Postwar Economic Order." International Organization 36(2): 379-415.

Sattler, Thomas, John R. Freeman, and Patrick T. Brandt. 2008. "Political Accountability and the Room to Maneuver: A Search for a Causal Chain.” Comparative Political Studies 41(9): 1212-39.

Sattler, Thomas, Patrick T. Brandt, and John R. Freeman. 2010. "Democratic Accountability in Open Economies.” Quarterly Journal of Political Science 5(1): 71-97.

Schmidt, Vivien A. 2007. “Trapped by Their Ideas: French Élites' Discourses of European Integration and Globalization." Journal of European Public Policy 14(7): 992-1009.

Walter, Stefanie. 2010. "Globalization and the Welfare State: Testing the Microfoundations of the Compensation Hypothesis." International Studies Quarterly 54(2): 403-426.

Weaver, R Kent. 1986. “The Politics of Blame Avoidance.” Journal of Public Policy 6(4): 371398.

Zaller, John, and Dennis Chiu. 1996. “Government's Little Helper: U.S. Press Coverage of Foreign Policy Crises, 1945-1991." Political Communication 13(4): 385-405. 


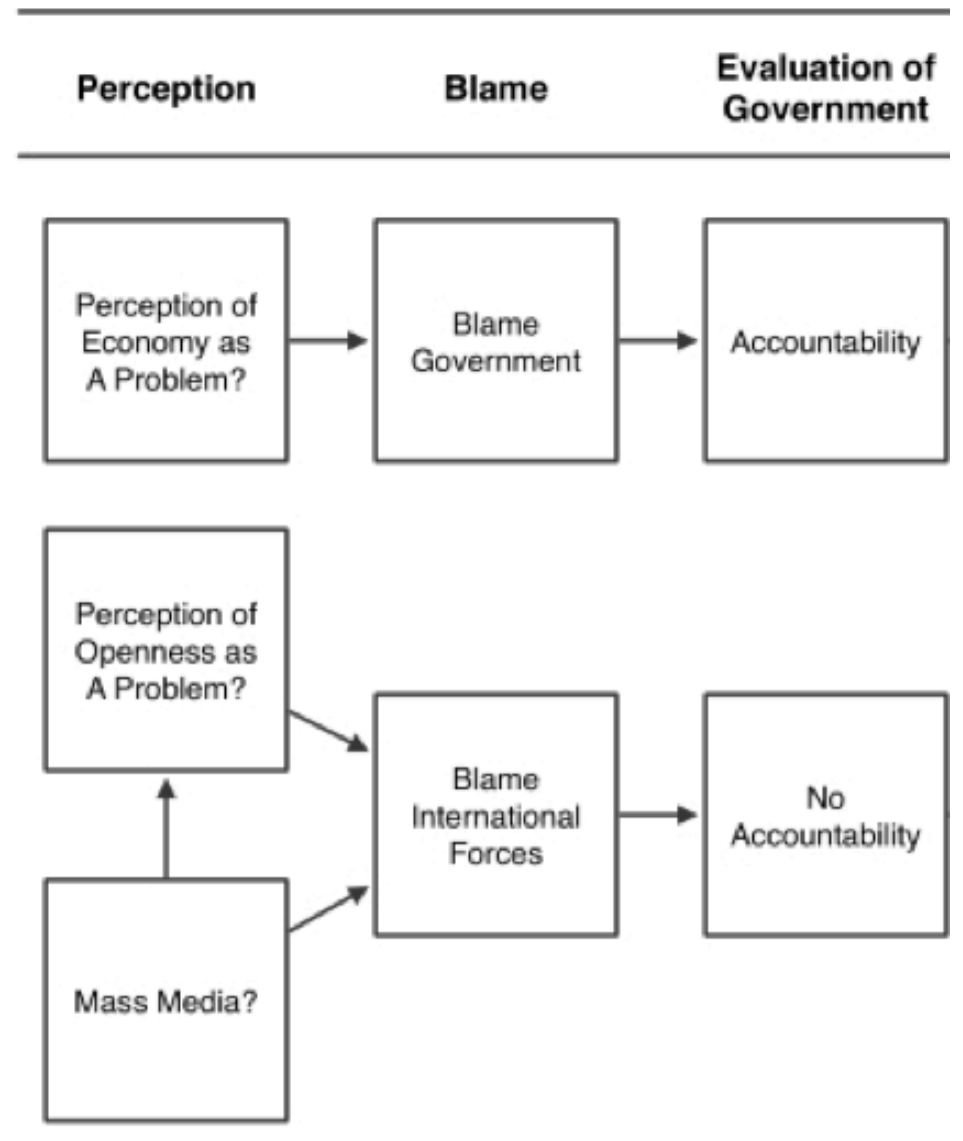

Figure 1: Summary of the Hypothesized Effects of Mass Media and Perception in the Domestic Politics of Economic Liberalization 


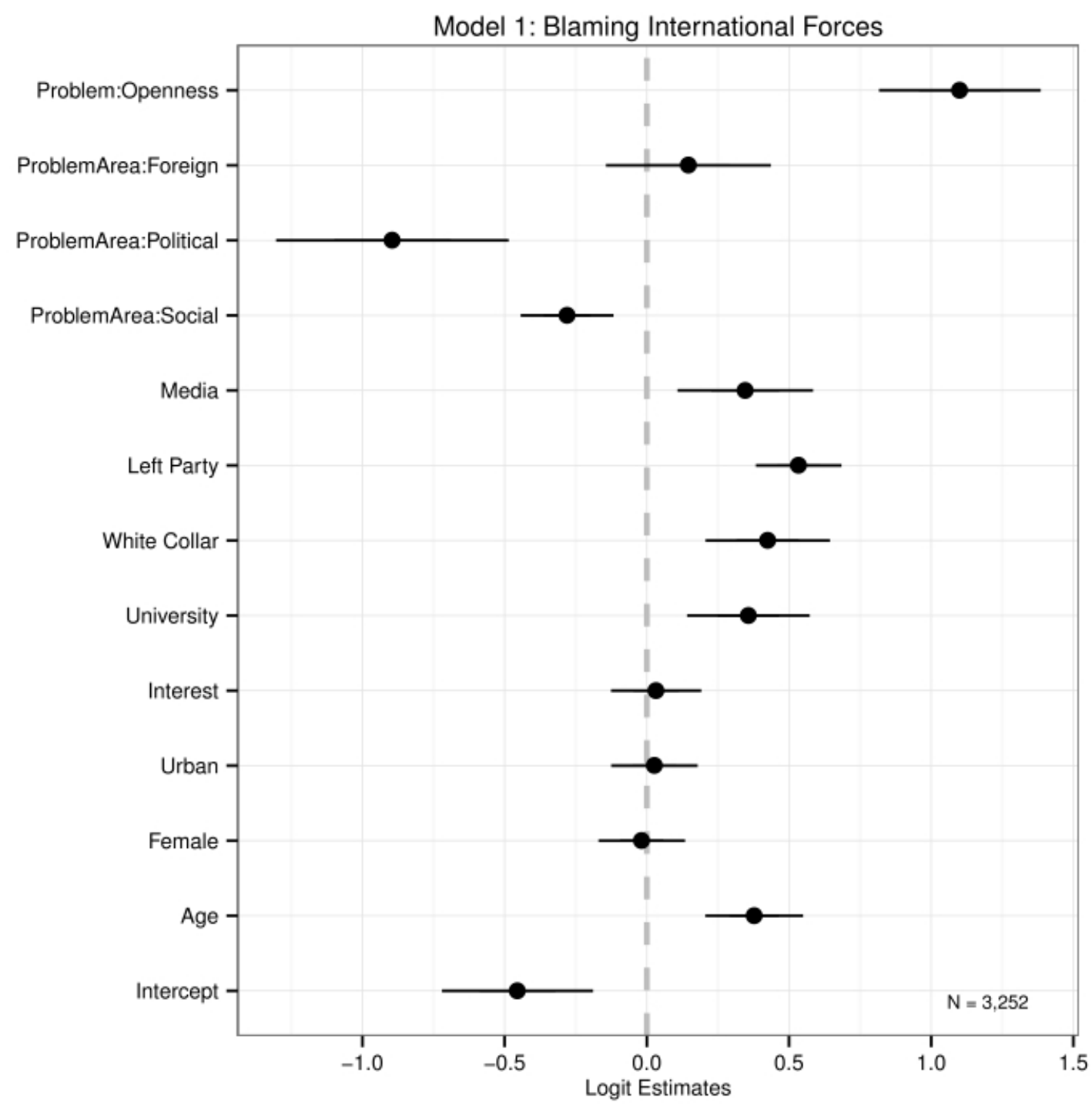

Figure 2: Determinants of Blaming International Forces 


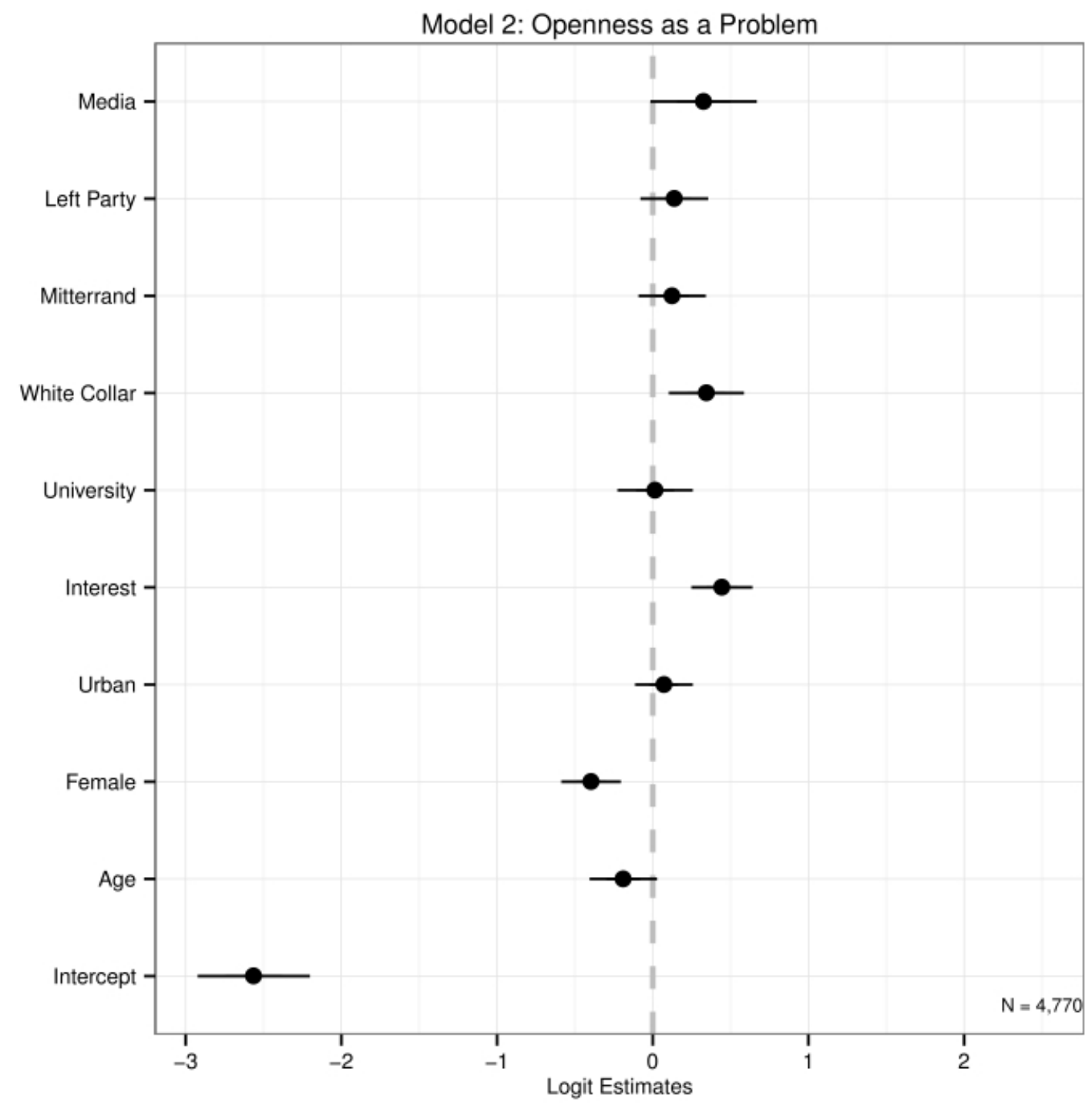

Figure 3: Determinants of Perceiving Openness as a Top Problem 


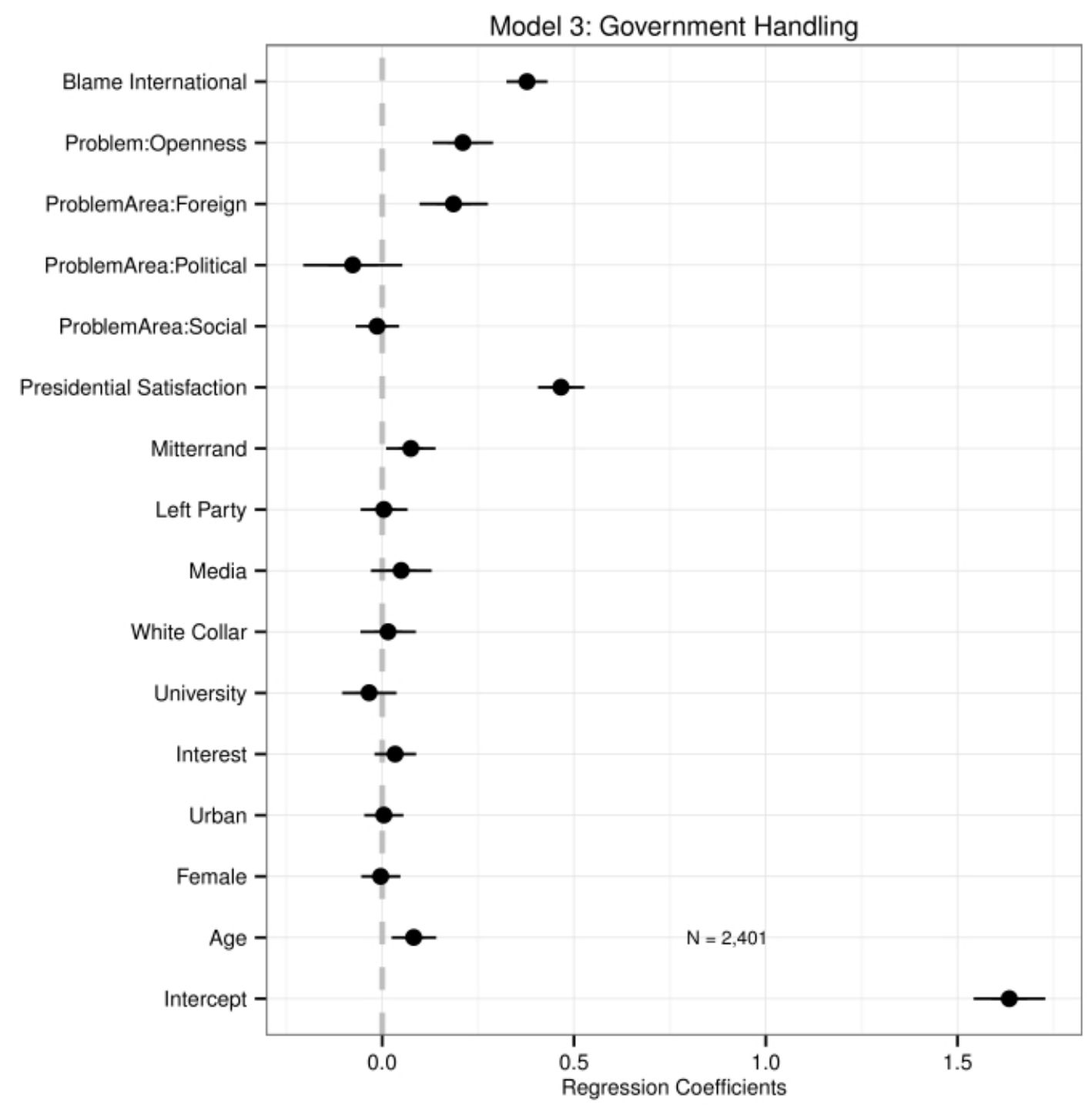

Figure 4: Determinants of Government Evaluations 